\title{
LA RELIGIÓN CATÓLICA EN GIBRALTAR Y MENORCA EN EL SIGLO XVIII: MODELOS DE COEXISTENCIA DURANTE EL DOMINIO BRITÁNICO
}

\author{
David González Cruz \\ Universidad de Huelva
}

\begin{abstract}
RESUMEN. Este trabajo estudia el funcionamiento del catolicismo en Gibraltar y Menorca una vez que pasaron al dominio de Inglaterra. La investigación presenta como innovación el análisis conjunto de ambos territorios en los que los hispanos tuvieron que convivir con la religión anglicana y con unas autoridades británicas interesadas en impedir la jurisdicción de la jerarquía eclesiástica. El texto se ha estructurado en varios apartados en los que se examina la situación en que quedaron los lugares sagrados (iglesias, conventos y ermitas) tras la ocupación anglosajona, se revisa la práctica de la fe católica en el contexto de ambigüedad del denominado «libre ejercicio de la religión» acordado en Utrecht, se detectan los obstáculos impuestos por el poder civil y militar a las potestades jurisdiccionales de los obispos de Mallorca y Cádiz, y se atiende al posicionamiento que tuvo la Santa Sede respecto a los procedimientos utilizados por los gobernantes ingleses.
\end{abstract}

Palabras clave: religión, catolicismo, Gibraltar, Menorca, Inglaterra

ABSTRACT. This work studies the functioning of Catholicism in Gibraltar and Menorca once they came under the rule of England. The research presents as an innovation the joint analysis of both territories in which Hispanics had to coexist with the Anglican religion and with British authorities interested in obstructing the jurisdiction of the ecclesiastical hierarchy. The text has been structured in several sections in which the situation in which the sacred places (churches, convents and hermitages) remained after the Anglo-Saxon occupation is examined, the practice of the Catholic faith is reviewed in the context of ambiguity of the so-called «free exercise of religion» agreed in Utrecht, the obstacles imposed by the civil and military power to the jurisdictional powers of the bishops of Mallorca and Cádiz are detected, and the position that the Holy See had regarding the procedures used by the English rulers.

Keywords: religion, catholicism, Gibraltar, Menorca, England

Recibido: 2-2-2021 . Aceptado: 21-4-2021.david@uhu.es 
LA CRISIS SUCESORIA ORIGINADA tras la muerte del rey Carlos II combinó su condición de guerra civil con el componente de conflicto bélico internacional que supuso la participación de diferentes potencias europeas teniendo, entre otras consecuencias, que el peñón de Gibraltar y la isla de Menorca pasaran al dominio británico en 1704 y 1708, respectivamente, tras ser conquistadas por la flota angloholandesa. Con posterioridad, el tratado de Utrecht, firmado en 1713, reconocía a la monarquía inglesa la posesión de ambos territorios. Si bien Gibraltar permaneció desde entonces bajo la órbita británica, en el caso de Menorca se produjeron diversos acontecimientos durante el siglo XVIII que motivaron la existencia de diferentes periodos de dependencia respecto a otros estados (Crespo, 2015, p. 268; Torres, 2009, pp. 413-414; Barro, 2019, p. 878; Morcillo, 2015, p. 24; Morales, 1987, pp. 383-384). En concreto, desde 1708 hasta 1756 la isla estuvo bajo la potestad de la corona inglesa; inmediatamente después fue ocupada por las tropas francesas dirigidas por el duque de Richelieu durante la guerra de los Siete Años hasta ser devuelta al rey Jorge III al ejecutarse el tratado de París en 1763; en 1782 sería reconquistada por la corona española permaneciendo bajo su soberanía hasta 1798, cuando pasó a ser tutelada de nuevo por la monarquía británica durante algo más de tres años hasta que, en 1802, se convirtió de forma definitiva en dominio hispano como resultado del tratado de paz de Amiens.

En este marco cronológico Gibraltar y Menorca — esta última controlada durante el periodo por las autoridades anglosajonas - pasaron de ser territorios en los que estaba permitida la fe católica como única religión oficial a convertirse en lugares donde convivieron diferentes credos de procedencia muy diversa (protestante - sobre todo anglicano- , cristiano ortodoxo, católico, judío y musulmán). Y esto, a pesar de que el Reino Unido se comprometía en el tratado de Utrecht a no consentir «por motivo alguno que judíos, ni moros habiten ni tengan domicilio» en ellos ${ }^{1}$. Por tanto, puede decirse que el mencionado acuerdo de paz fue incumplido en esta materia, en particular, si tenemos en cuenta que se produjeron asentamientos de practicantes de estas religiones en estos territorios con el apoyo de los gobernantes ingleses. No obstante, en este trabajo no nos detendremos a analizar la relativa complejidad que supuso la aplicación del citado tratado en el ámbito religioso, ya que esta cuestión ha sido estudiada en profundidad en otro artículo que hemos elaborado recientemente, donde se atiende, para el conjunto de la Monarquía Hispánica, a las implicaciones que al respecto se derivaron de la firma de este tipo de convenios internacionales durante el siglo XVIII' ${ }^{2}$.

1 Tratado de paz y amistad ajustado entre la Corona de España y la de Gran Bretaña; concluido en Utrecht a 13 de julio de 1713; y ratificado en Madrid a 4 de agosto del mismo año (Colección de los tratados de paz, 1796-1801, pp. 249-250).

2 González Cruz, s.f. 
El cambio de soberanía en Menorca y Gibraltar hizo que ambos territorios se convirtiesen en crisoles religiosos, donde coexistían la práctica de la fe católica de los nativos con las creencias llevadas a ellos por quienes arribaron a estos enclaves estratégicos con posterioridad a la ocupación inglesa. En este sentido, el primer registro de población ordenado por Richard Kane — gobernador de Menorca entre 1712 y 1736 (Victory, 1924, p. 82) - permite constatar la convivencia en la isla de 400 españoles, 113 británicos, 414 genoveses, 137 judíos, 23 franceses, 21 neerlandeses y 5 musulmanes; en total, 1.113 censados (Crespo, 2014, p. 268). De igual modo, en Gibraltar estaban asentados en 1773, según el viajero Richard Twiss - miembro de la Royal Society_-, 2.000 ingleses, sin contar los militares de la guarnición, 700 genoveses, 300 españoles y portugueses, 600 judíos y unos «cientos de moros» que comerciaban continuamente con la costa de Berbería ${ }^{3}$. Por su parte, Ignacio López de Ayala — catedrático y miembro de la Real Academia de la Historia - informaba a fines del siglo XVIII que unos años antes, en 1776, residían en esta plaza 3.000 personas (López, 1782, p. 373), aproximadamente: 500 de nacionalidad inglesa, 1.000 judíos y 1.400 católicos (sumados los españoles, portugueses e italianos, estos últimos mayoritarios). Asimismo, el general Robert Boyd se hacía eco de la diversidad cultural de los habitantes de Gibraltar en la lista elaborada en 1777, al reseñar en ella que se habían establecido 519 británicos, 62 menorquines, 134 españoles, 672 genoveses y saboyardos, 93 portugueses, 13 franceses, 863 judíos y 845 católicos, estos últimos nacidos en la plaza (Crespo, 2014, p. 270)

Aunque las cifras aportadas por los diversos testimonios no coinciden con exactitud, sí son indicativas de la representatividad proporcional de las diferentes religiones profesadas en este territorio bajo el control de la corona británica (anglicana, católica, judía y musulmana, en este último caso si se considera a los comerciantes que habitualmente traficaban con Berbería). El testimonio ofrecido por Pablo de Mena - comisario del Santo Oficio en Tarifa_- en su informe remitido en 1712 al tribunal de la Inquisición, ofrecía algunos detalles más sobre la nacionalidad y procedencia de los pobladores de Gibraltar con posterioridad a la ocupación inglesa. Así, daba cuenta de la residencia de holandeses, irlandeses, escoceses, ingleses, genoveses, catalanes, mallorquines, napolitanos, valencianos, judíos y moros (Domínguez Ortiz, 1994, p. 191).

3 De esta manera describía la distribución poblacional de Gibraltar en su obra traducida al idioma francés: «Il a une église Angloise, \& une autre pour le service des Espagnols \& des Portugais, que font ici au nombre d'eviron 300, prèsque tous tenant boutique, \& pour celui de 700 Gênois, la plupart marins, \& une synagogue pour environ 600 Juifs établis ici. Je crois que sans compter la garnison il y a dans Gibraltar environ 2000 personnes Angloises. Quelques centaines de Maures y vont \& viennent continuellement des cótes de Barbarie, faisant un commerce de bêtail, de gibier, de poisson $\&$ de fruits» (Twiss, 1776, p. 304). 
Este panorama de orígenes distintos y credos diversos configuraba una realidad social multicultural y pluri-religiosa en dos territorios aislados políticamente de la Península Ibérica, cuya población tuvo que convivir, o al menos coexistir, durante gran parte del siglo XVIII bajo la supervisión de las autoridades británicas. Se trataban de dos espacios geográficos que conformaron un contexto histórico en el que se escenificó la tolerancia o, en su caso, la intolerancia religiosa. Por esta razón, este artículo se integra en una línea de investigación afín a otros análisis historiográficos, como los realizados en su día por Henry Kamen en su clásico Nacimiento y desarrollo de la tolerancia en la Europa Moderna (1967), o, ya más recientemente, la serie de trabajos que conforman el monográfico editado por la revista Annales de Bretagne et des Pays de l'Ouest bajo el título «Tolerance et intolerance des religions en Europe, XVIe-XVIIIe siècle» (2018). Y eso sin olvidar los materiales publicados desde 2007 por el Cercle d'Histoire de l'Université Libre de Bruxelles bajo el epígrafe «Tolérance et intolerance religieuse dans l'histoire: Moyen Âge, Temps moderne et époque contemporaine», y a los que se suman los trabajos elaborados, entre otros, por Juan Pablo Domínguez (2013) y Eduardo Bello (2004).

En el presente estudio hemos tratado de examinar la práctica de la religión católica y el funcionamiento eclesiástico en dos lugares distantes geográficamente (Gibraltar y Menorca), pero cuyo denominador común es el de encontrarse sujetos al dominio británico en el siglo XVIII. Es pues la primera vez que se analiza de manera conjunta el devenir de la Iglesia católica en territorios que, inicialmente, formaron parte de la Monarquía Hispánica, lo que nos ha llevado a realizar una investigación con documentación procedente del Archivo General de Simancas (Valladolid), Archivo Histórico Nacional (Madrid), Archivio Segreto Vaticano (Roma), Archivo General Militar (Madrid) y fondos antiguos de distintas bibliotecas universitarias. A estas fuentes se ha sumado la información procedente de colecciones jurídicas, tratados internacionales, relatos de viajes y descripciones histórico-geográficas. Esto ha posibilitado en un segundo momento cruzar dicha información y ofrecer así una visión global sobre la temática abordada. Debido a las lógicas limitaciones de espacio, hemos decidido analizar todo lo referido a la religiosidad de las comunidades judía y musulmana en una publicación específica que en estos momentos se encuentra en curso de elaboración, por lo que en esta nos hemos centrado en lo sucedido con el catolicismo.

\section{Iglesias, conventos y ermitas: entre tolerancia, irreverencia y profanación}

Una vez que Gibraltar y Menorca pasaron a la jurisdicción inglesa surge la cuestión de la gestión de los diferentes lugares de culto sagrado, los cuales, en princi- 
pio, debían respetarse como centros para la práctica de la fe católica atendiendo a lo estipulado en los artículos X y XI del tratado de Utrecht, los cuales comprometían a la corona británica a permitir el «uso libre de la religión católica romana» y a que los seglares y eclesiásticos de esta religión gozasen «segura y pacíficamente de todos sus bienes» (Colección de los tratados, 1796, vol. 1, pp. 249-250).

En Gibraltar, y según el informe realizado en 1712 por Juan García de la Yedra - comisario del Santo Oficio de Cádiz-, gracias a las noticias proporcionadas por gibraltareños y gaditanos que mantenían negocios con esta plaza, se conservaron los cultos en la parroquia de Santa María, regida por el párroco y vicario Juan Romero Figueroa, administrándose los sacramentos en ella, si bien las autoridades que ocuparon la Roca no consentían que los ingleses e irlandeses católicos asistiesen al templo y profesasen la fe católica (Domínguez Ortiz, 1996, p. 307). En cambio, los conventos estaban cerrados o se destinaban los edificios para funciones profanas. En esa fecha, sólo permanecía abierto el convento de los franciscanos observantes, que era atendido por dos religiosos; el retablo y las imágenes habían sido maltratadas, mientras que el grueso del edificio se utilizaba como alojamiento para el gobernador inglés. Más tarde, se convertiría en el palacio residencial permanente del mencionado gobernador, por lo que su iglesia se transformó en un templo anglicano al que concurrían los británicos a «toque de tambor» (Bethencourt, 1996, pp. 24-25; López, 1782, p. 372). Por su lado, el convento de los mercedarios, tradicionalmente dedicado a la redención de cautivos cristianos, fue utilizado como casa del Almirantazgo, y el de San Juan de Dios se usaba como tienda y almacén. Por último, el cenobio femenino de Santa Clara fue destinado a barracas para las fuerzas de la guarnición, mientras que sus monjas tuvieron que abandonar el Peñón y refugiarse en el convento de padres recoletos de la localidad de Jimena, desde donde serían recolocadas luego en diversas comunidades religiosas - Santa Isabel de Ronda; Santa Clara y Santa Inés de Sevilla; Madre de Dios de Jerez; Santa Clara de Osuna, Morón, Marchena, Antequera y Carmona- (López, 1782, pp. 292-293).

A este conjunto de edificios religiosos enajenados habría que sumar las ermitas de Nuestra Señora de la Cabeza, de la Vera-Cruz ${ }^{4}$, de la Plaza Mayor, junto al hospital de la Misericordia, de Nuestra Señora del Rosario, de San Juan el Verde y de Nuestra Señora de los Remedios (Romero, 2014, pp. 347-348; López, 1782, pp. 31 y 6163). Por su parte, la ermita de la Virgen de Europa, cuya imagen generaba una gran devoción y fervor entre los gibraltareños, fue saqueada por las fuerzas de ocupación

4 Francisco García Caballero, cónsul español en Gibraltar, informaba en una carta al marqués de Grimaldo que en 1718 solo se encontraban bajo la dependencia de los católicos la Iglesia Mayor y la ermita de la Santa Vera-Cruz. Archivo General de Simancas (en adelante AGS), Estado, 6841, s. fol. 
en 1704 , tal y como rezan los testimonios de los contemporáneos ${ }^{5}$. Al respecto, las fuentes consultadas destacan el sacrilegio cometido por las fuerzas de ocupación del Peñón con esta imagen de la madre de Cristo. De ello daba cuenta ya en su día el académico López de Ayala:

Profanaron todas las iglesias a excepción de la mayor que defendió con su presencia el celoso cura Don Juan Romero. Donde executaron más desórdenes fue en la virgen de Europa, maltrataron la imagen con irrisión, i cortaron la cabeza al niño que tenía en sus brazos. Pudose no obstante recobrar, i se colocó en el altar del sagrario de la iglesia mayor sin que faltase nada a la imagen, pues una muger piadosa logró recoger la cabeza que habían separado los irreligiosos vencedores (López, 1782, p. 289).

La confianza que tenían los habitantes en las cualidades milagrosas de Nuestra Señora de Europa hizo que durante el conflicto las mujeres, niños y la gente denominada «inútil para la defensa» se refugiaran en su santuario, de manera que en el curso de los desplazamientos que todos ellos hicieron entre el núcleo urbano y el lugar donde estaba situada la citada ermita fueron víctimas de la artillería de los navíos durante el proceso de conquista de la plaza. Una situación que fue descrita como «un espectáculo que pudiera mover la compasión de los mismos enemigos» (López, 1782, pp. 286-287).

Acerca de las profanaciones de templos y comunidades religiosas, la documentación española atestigua este tipo de conductas de los ingleses tanto en Gibraltar como en Menorca con posterioridad a la firma del tratado de Utrecht, lo cual suponía un incumplimiento manifiesto de los artículos X y XI del mencionado convenio internacional. En relación con este asunto el marqués de Lede —capitán general de Mallorca - informaba el 9 de marzo de 1717 al marqués de Grimaldo - secretario del Despacho de Estado-, sobre las actuaciones que había promovido Richard Kane - gobernador de Menorca - vulnerando el tratado ${ }^{6}$. Entre ellas, afirmaba que los británicos habían ocupado las iglesias del castillo de Mahón, el hospital instalado en el castillo de Fornells y la iglesia de San Pedro, donde habían secuestrado el viático que se llevaba a un enfermo, además de abrir las puertas del sagrario del convento de San Diego de Alayor, profanando las formas sagradas que en él se custodiaban, y maltratado al vicario general del convento de San Agustín y al guardián del convento de San Francisco de Mahón. Con estos precedentes, el

5 Entre otros autores que hicieron mención a estos acontecimientos figura un canónigo granadino que se hacía eco de ellos: "Ya se dize, que en una hermita fuera de los muros, unos ingleses despojaron a la milagrosa imagen de Nuestra Señora de Europa, y después la hizieron pedaços» (Marín, 1704, p. 2).

AGS, Estado, 6834, exp. 125, s. fol. 
Consejo de Estado, previa realización de consultas y valoración de las cartas remitidas por el comandante de Mallorca y el cabildo de su catedral, estudiaba la situación el tres de julio de 1717, haciéndose eco entonces de que los británicos estaban violando los acuerdos de paz de 1713, pues:

[...] han llegado hasta profanar las vírgenes que están en los conventos, pues rompen las fianzas y puertas de las clausuras, maltratan los sacerdotes y llegan hasta profanar el Sanctissimo Cuerpo de Jesuchristo, registrando los sagrarios?

Como consecuencia de este posicionamiento de la administración española, el marqués de Monteleón, embajador en Londres, llevó a cabo nuevos contactos diplomáticos con el secretario de estado Paul Methuen. Ante la postura que había mantenido anteriormente el ministerio británico al afirmar desconocer este tipo de infracciones, el citado marqués le recordaba que la cesión de Menorca por la corona española se efectuó «bajo la condición formal de que el uso de la religión católica romana se había de mantener allí inviolablemente»y, por ello, instaba a que el rey Jorge I diera órdenes al comandante de Menorca para que no turbase a los habitantes de la isla el libre ejercicio del catolicismo ${ }^{8}$.

Dado el riesgo que suponía que los lugares sagrados fuesen objeto de sacrilegios por parte de los militares ingleses, algunos clérigos que se quedaron en Gibraltar tras la ocupación se dedicaron a proteger las imágenes y alhajas de los templos, guardándolas en espacios seguros y a organizar, con la ayuda de personas de confianza, su paulatino transporte al pueblo de San Roque y otras localidades del entorno9. Valga de ejemplo una síntesis del relato redactado por el cura gibraltareño Juan Romero, en relación con el procedimiento que empleó para salvaguardar la integridad de los objetos religiosos y la documentación eclesiástica, el cual quedaba reseñado con detalle en la obra del catedrático López de Ayala:

[...] pues tomó la resolución de extraer el archivo, las imágenes, halajas i ropas de la iglesia i conducirlas con el mayor sigilo al pueblo de San Roque. Con este designio quando veía en la plaza algunos Españoles sus paisanos, o de otros pueblos, personas que creía de silencio i confianza, los llamaba aparte, i encareciendo la obra de religión que iba a encomendarles, i al mismo tiempo el peligro que ambos corrían si fuesen descubiertos, les entregaba libro, lámpara, u otra halaja de la iglesia para que la dexasen en San Roque, o a los curas de sus tierras si no pasaban por aquella población $[\ldots]$ Por los mismo medios se sacaron, i recogieron quatro lámparas de

$7 \quad$ AGS, Estado, 6834, exp. 138, f. 7.

8 AGS, Estado, 6834, exp. 145, s. fol.

9 En una carta enviada a Felipe V por el obispo de Cádiz el 30 de diciembre de 1726 se le notificaba que le había encargado al vicario de la Iglesia de Gibraltar que resguardara los «los hornamentos y vasos sagrados y papeles del archivo». AGS, Estado, 6870, s. fol. 
plata, cinco cálices, naveta, incensario, tres ternos, mucha ropa, concha i ánforas de plata para los baptismos (López, 1782, pp. 323-325).

Asimismo, utilizando como fuente los escritos del citado sacerdote, López de Ayala dejaba constancia del modo en que las imágenes de culto habían sido extraídas de Gibraltar, ya fueran envueltas entre ropas o introducidas en grandes espuertas por los que se dedicaban a vender comestibles o por otros medios. Así se pusieron a salvo de profanaciones a la Virgen de los Dolores, del Socorro, de los Remedios, el Cristo de la Expiración, San José, el Cristo de la Columna, la Magdalena y San Antonio (López, 1782, p. 325). En este contexto, resulta curioso y creativo el recurso secreto utilizado para trasladar un gran busto escultórico de San José:

\begin{abstract}
Una estatua de San Josef, que por su corpulencia no se podía sacar oculta la trajo un católico llamado Josef Martín de Medina, colocándola sobre un caballo a imitación de una persona que lo montaba: la afianzó bien, la embozó con una capa, i la cubrió con una montera. Otro montado a la grupa ayudaba a sostener el santo, i agregándose algunos combidados para mayor confusión i disimulo salieron por la calle Real sin ser descubiertos (López, 1782, p. 325).
\end{abstract}

Aunque se produjeron algunas conductas irreverentes, también se aprecian actitudes tolerantes en los ocupantes ingleses de Gibraltar y Menorca, lo que posibilitó que al menos pudiera conservarse una parte significativa del patrimonio religioso en las décadas siguientes. Según el obispo de Mallorca, con motivo de una visita ad limina, informaba a la Santa Sede que Menorca disponía del siguiente patrimonio en 1712: cinco parroquias, cinco conventos masculinos y dos femeninos, así como «otros santuarios de singular devoción» ${ }^{10}$. Varias décadas después, en torno a 1778, se efectuaba una descripción de los establecimientos eclesiásticos existentes en la isla, pudiéndose apreciar que continuaban en pie el convento de los agustinos en el monte Toro, la parroquia de Ciudadela, con dos conventos de frailes y uno de monjas, las iglesias de Mahón, la parroquia de Alayor y el convento de San Diego, entre otros edificios religiosos (Espinalt, 1778, pp. 386 y 390-391). Aun así, algunos templos se destinaron a la celebración de cultos anglicanos, tal como ocurrió con la iglesia de San José de Mahón (Morales, 1987, p. 385). Pero, sea cual fuere la fe que se practicaba en cada lugar sagrado, lo cierto es que a fines del siglo XVIII, a pesar de la conquista británica, pervivían testimonios materiales en forma de edificaciones que eran expresivas de las raíces católicas tanto de Menorca como de Gibraltar. 


\section{Jurisdicción civil versus jurisdicción eclesiástica}

El traspaso jurídico de Menorca y de Gibraltar del dominio español al británico resultaba una cuestión compleja si tenemos en cuenta la ausencia de determinados detalles en el articulado expresado en el tratado de Utrecht, así como el hecho de que el cambio de la posesión se llevaba a efecto entre dos coronas que de un modo u otro tenían potestades, ya fuera con respecto al anglicanismo o ya fuese en relación con la Iglesia católica. Así, el monarca inglés era cabeza de la Iglesia anglicana al mismo tiempo que cúspide del poder temporal. Por su parte, el rey de España compartía su autoridad política con su capacidad para proponer los nombramientos de miembros de la jerarquía clerical mediante el sistema de patronato eclesiástico. Por tanto, en ambas monarquías se producían conexiones manifiestas entre el absolutismo de estado y el control del ámbito espiritual de los súbditos. En este marco resulta lógico que los gobernantes anglosajones trataran de limitar las competencias eclesiásticas en los territorios conquistados como instrumento para evitar las injerencias que pudieran producirse como consecuencia de la influencia que la Monarquía Hispánica poseía sobre los obispos de Cádiz (con jurisdicción en Gibraltar) y Mallorca (con atribuciones en la isla de Menorca), igual que en relación con el Santo Oficio de la Inquisición - un tribunal de carácter religioso, pero dependiente del rey de España, en cuanto que éste decidía la designación del Inquisidor General—. De este modo, la conservación de una jurisdicción católica de carácter externo en Menorca y Gibraltar podía suponer que, de manera indirecta, a través de los titulares de las diócesis existiera el riesgo de un posible influjo de la Santa Sede y de los Borbones por la vía espiritual en los habitantes de ambos territorios, y ello a pesar de que habían pasado a tener la condición de súbditos de la corona inglesa.

Teniendo en cuenta este entramado estructural de alianzas entre los poderes temporales y religiosos, Richard Kane — gobernador de Menorca — intentó eliminar las interferencias que pudieran haberse generado desde el lado hispano y, por este motivo, dio las órdenes pertinentes al vicario general eclesiástico de la isla en 1717 para que no se admitieran las actuaciones de dos pilares institucionales con capacidad de control sobre la población: la Inquisición y los tribunales diocesanos de Mallorca ${ }^{11}$. A estos mandatos que promovían el total aislamiento respecto a cualquier autoridad que hubiera tenido potestades en esta isla en siglos anteriores - espirituales incluidas-, sumaba la exigencia de manifestar muestras de sumisión a la monarquía británica que supusieran la aceptación formal del nuevo poder establecido. De ahí que el citado gobernador obligara a los clérigos católicos a prestarle juramento de fidelidad y a 
llevar a cabo oraciones públicas por el rey de Inglaterra ${ }^{12}$, al tiempo que desterraba al vicario general por defender «la jurisdicción y la disciplina eclesiástica» ${ }^{13}$.

Disposiciones de este tipo sobre los menorquines originaron un frecuente forcejeo diplomático durante el siglo XVIII en defensa de los respectivos intereses de las dos coronas, activándose cada vez que se adoptaba alguna medida de este cariz por parte de los dirigentes británicos. De ello se hacía eco el marqués de Casafuerte, comandante general del reino de Mallorca, el 16 de septiembre de 1717, cuando aludía a las gestiones que el embajador español realizó ante el gobierno inglés en defensa de las jurisdicciones diocesana y de la Inquisición tras las órdenes dictadas por Richard Kane:

Y que haviéndose conformado el Rey [Felipe V] con la resolución tomada por la Congregación de Inquisidores en esta dependencia me previene V.S. de la que S.M. ha tomado a las pretensiones del Governador de Menorca, para que disponga se participe a los cathólicos que residen en aquella isla, diciéndome: Que en el primer punto de pretender ingleses, que los eclesiásticos, así seculares, como regulares residentes en Menorca, no obedezcan a los superiores que estuvieren fuera de la isla, el contradecir a la immunidad eclesiástica local, a la jurisdizión de la Inquisición, y al despacho de los beneficios; respecto a que sobre esto, están mandados pasar vivos oficios con el Ministro de Inglaterra, y con aquella Corte, ha resuelto S.M. se espere a ver el efecto que producen, y según él, se apliquen los medios más proporcionados, para que ingleses cumplan lo que en esto está capitulado ${ }^{14}$.

En este contexto, los gobernantes de la isla mostraron un especial interés en que los menorquines juraran fidelidad y obediencia al monarca británico como fórmula de acatamiento completo de la condición de vasallos. No obstante, este asunto generó ciertas reticencias en los católicos como consecuencia del debate teológico que se suscitó respecto a los términos en que debía producirse el mencionado juramento; principalmente porque podría llegar a ser un «error herético» por tratarse del cabeza de la Iglesia anglicana ${ }^{15}$. En este sentido, José Rodrigo — secretario de Felipe Vargumentaba, en una carta dirigida al marqués de Grimaldo en 1724, que aunque las

12 En torno a la exigencia del gobernador de Menorca comunicada a los católicos de la isla para que hicieran rogativas en honor del rey de Gran Bretaña se expresaba el obispo de Mallorca en una carta dirigida al marqués de Grimaldo el 4 de febrero de 1768: «... [el gobernador] no quiso dar Audiencia sino al Vicario, y a este delante de su escribano y otros dos ingleses, le dijo [...] como que no hacían rogativas por su Soverano, como lo havían hecho por el de Francia, quando posehía la Isla; a que procuró satisfacerle con que todos los días le encomendavan a Dios, y pedían por él en el santo sacrificio de la misa; y también huvieran hecho rogativas si lo huviere insinuado, y estaban prontos a hacerlas siempre que lo quisiese, o huviere alguna necesidad». AGS, Estado, 6968, s. fol. 13 AGS, Estado, 6834, exp. 125, s. fol.

14 Carta del marqués de Casafuerte al marqués de Grimaldo — secretario de Estado-. AGS, Estado, 6834, exp. 151, s. fol. Ibídem. 
autoridades inglesas afirmaban que consistía en un acto meramente civil y político, la dificultad la encontraba en la «forma y substancia» en que se quería formalizar, ya que pretendían que no se reconociera en la tierra a ningún hombre superior al rey de Inglaterra, lo que advertía podía suponer indirectamente la negación de la potestad del Papa y, de esta manera, una contravención a la fe católica ${ }^{16}$.

La vinculación de los menorquines con la diócesis de Mallorca generaba resistencias en las autoridades británicas, tal como dejaba constancia el obispo Francisco García de la Vega en 1768, al manifestar que el gobernador de la isla no lo reconocía como superior eclesiástico por su condición de vasallo de otro monarca ${ }^{17}$. Una situación semejante se aprecia en Gibraltar, donde el prelado de Cádiz y un comisionado suyo no pudieron visitar la plaza porque el gobernador Robert Boyd declaraba ese mismo año que no permitiría que hubiese una jurisdicción distinta a la suya. Por supuesto, esta afirmación contó con el desacuerdo del mariscal Diego Tabares - comandante general del Campo de Gibraltar-, quien consideraba que esta actitud era contraria a los tratados de Utrecht por impedir el libre ejercicio de la religión, pues estimaba que no respetaba la subordinación de los clérigos gibraltareños al obispo de Cádiz e impedía «remediar los abusos con muchos perjuicios espirituales, y sería permitir un Anti Papa independiente de otro juez eclesiástico» ${ }^{18}$.

Desde luego, las facultades jurisdiccionales de los obispos se encontraban muy mermadas en estos dominios británicos; no en vano, en esta fecha había transcurrido medio siglo desde que el obispo Lorenzo Armengual fue autorizado en 1717 a entrar en la Roca ${ }^{19}$. La diplomacia inglesa, conocedora del compromiso de Utrecht y en el intento de que su postura no se considerara una infracción del convenio internacional firmado en 1713, utilizó con frecuencia la estrategia de no responder a las peticiones de autorización de visitas pastorales solicitadas por las diócesis de Mallorca y Cádiz y el procedimiento de salir al paso contestando con fórmulas dilatorias ${ }^{20}$. No obstante, lord Townshend — secretario de estado — le comentó al marqués de Pozobueno

16 AGS, Estado, 6864, s. fol.

17 Carta del obispo de Mallorca al marqués José Grimaldo, firmada el 4 de febrero de 1768. AGS, Estado, 6968, s. fol.

18 Informe del mariscal Diego Tabares dirigido a Juan Gregorio Muniain — secretario de GuerraCampo de Gibraltar, 6 de abril de 1768. AGS, Estado, 6968, s. fol.

19 AGS, Estado, 6968, exp. 1350, s. fol.

20 En efecto, una muestra del procedimiento utilizado por la diplomacia inglesa para demorar la respuesta con ambigüedades nos la presentaba el marqués de Pozobueno -embajador en Londres - en la carta que envió al conde de Riperdá el 31 de enero de 1726: «[...] y pocos días antes de mi partencia para Inglaterra el secretario de estado milord Townsend me hizo saver allí, que había pedido informe al Duque de Newcastle, a quien a mi arrivo a esta capital hize instancia para llegar a saver lo que deveríadar quenta en orden a esta solicitud, y me respondió afirmando havía escrito sobre ella, pero no se acordó positivamente si fue a Dn. Guillermo Stanhope, o al comandante de Gibraltar, y añadió, que según el tiempo que havía pasado creía, que podía haver hecho su visita el Sor. obispo [...] Londres, 31 de enero de 1726». AGS, Estado, 6867, s. fol. 
— embajador en Londres - que este tipo de actividades episcopales eran «poco gratas» a su ministerio (Bethencourt, 1967, p. 385). De esta manera el silencio premeditado constituyó un obstáculo recurrente que dificultó a los prelados tener relaciones directas con sus feligreses e impartirles el sacramento de la confirmación en sus correspondientes lugares de residencia. De esta situación se quejaba el obispo de Cádiz en dos documentos remitidos al marqués de la Ensenada y a José de Carvajal y Lancaster con motivo de su visita a tres localidades del Campo de Gibraltar en 1749:

[...] summa aflicción e inconsolable pena porque estar quassi tocando las murallas y puerta de una ciudad, cuia grey cathólica es mía, y cuia iglesia es la más preciosa prenda, que adorna mi Mithra, y no poder entrar a visitarla, consolarla, y dirigirla, quando tanta necesidad tiene, quanta yo see y expondré a V. Exa. de ser visitada, consolada, governada, e instruida $[\ldots]^{21}$

[...] tiene por fundamental vasa la subordinación y obediencia a los obispos proprios, legítimos dueños en lo espiritual de el territorio en que los fieles sus dioces sanos avitan. De otro modo no se puede verificar el egercicio libre de nuestra religión; y dejará de ser libre, siempre que la potestad secular lo subjugare a reconocer otro ordinario, distinto de aquel, en cuio gremio ha nacido la porción o grey catholica, destinada por el Pastor universal a este, o a aquel particular obispo ${ }^{22}$.

Si bien hubo numerosos impedimentos por parte de las autoridades inglesas para evitar que los prelados mantuvieran la comunicación directa con los católicos de Gibraltar y Menorca, y ello a pesar de las continuas gestiones desarrolladas por los embajadores españoles ante la corona británica, también es cierto que se produjeron algunas excepciones manifestadas en las visitas pastorales realizadas por el obispo de Cádiz a Gibraltar a fines de 1717 y por el de Mallorca a Menorca en 1755. En ambos casos los gobernantes ingleses concedieron una atención digna de su jerarquía a los dos eclesiásticos mitrados. Por un lado, Lorenzo Armengual fue invitado a comer con el gobernador de la Roca y los miembros del séquito estuvieron hospedados en su palacio (Bethencourt, 1967, pp. 39-40); por otro, el prelado Lorenzo Despuig, tras su regreso de Menorca en 1755, declaraba el «buen trato que había experimentado de parte de aquel gobernador y demás oficiales ingleses $\rangle^{23}$.

La posición anglosajona ante las visitas episcopales era una manifestación - y no única- de la defensa de la jurisdicción plena sobre los territorios conquistados

21 Carta del prelado Tomás del Valle al marqués de la Ensenada, Puerto Real a 30 de junio de 1749. AGS, Estado, 6832, s. fol.

22 Carta del obispo Tomás del Valle a José de Carvajal y Lancaster — ministro de Estado—, Cádiz a 19 de agosto de 1749. AGS, Estado, 6832, s. fol.

23 Carta de Félix de Abreu — enviado extraordinario a la corte de Inglaterra - dirigida a Ricardo Wall, Londres a 13 de noviembre de 1755. AGS, Estado, 6929, s. fol. 
durante la guerra de Sucesión. Las autoridades de Menorca y Gibraltar pusieron su empeño en evitar que las conexiones eclesiásticas pudieran propiciar determinadas injerencias en el dominio efectivo de ambas plazas. Las órdenes difundidas por el gobernador Richard Kane en 1721 y confirmadas por el rey Jorge I, en su artículo 4, insistían en esta cuestión, ya que advertían que «ninguna persona eclesiástica, secular, o regular debe acudir, o recibir órdenes de Mallorca, o de los dominios de España, o mantener su autoridad en Menorca, apelar delante de ellas en materia alguna, o a sus tribunales», puesto que si lo hacían estaba previsto el castigo de destierro ${ }^{24}$. Como muestra de las sanciones impuestas a este respecto, el propio vicario general de la isla, el doctor Cristóbal Rubí, padeció esta pena unos años antes a causa del rigor con que actuó Kane ${ }^{25}$. De igual modo, el sitio del Peñón efectuado en 1727 fue la excusa utilizada por los británicos para expulsar a eclesiásticos de esta plaza (Bethencourt, 1967, p. 51). Asimismo, en Gibraltar se han podido apreciar situaciones de discriminación de los católicos, pues eran encarcelados por cualquier motivo o se les obligaba a realizar trabajos de manera frecuente tales como retirar la basura de las calles (Morgado, 2008, p. 38).

En este marco, los gobernantes de Menorca extremaron la vigilancia y el celo en relación con los eclesiásticos prohibiendo la llegada de misioneros, no admitiendo a los clérigos que no eran naturales de la isla y que querían ostentar sus beneficios, al tiempo que secuestraban las rentas y diezmos que pertenecían al obispo de Mallorca y a su cabildo catedralicio ${ }^{26}$. Por su parte, los responsables políticos gibraltareños trataron de limitar, aún más, la potestad jurisdiccional de los prelados obstaculizando el nombramiento de los clérigos católicos mediante el empleo de diferentes procedimientos, ya fuera impidiendo la entrada en la Roca de un eclesiástico que ayudara y pudiera sustituir en caso de necesidad al cura y vicario general de edad avanzada ${ }^{27}$, ya fuese poniendo como condición que los sacerdotes fueran elegidos por los españoles que vivían en la plaza. De esta manera se coartaba, con un argumento interesado de pretendida base democrática, la libre voluntad del obispo gaditano para efectuar las designaciones $^{28}$, o se permitía que los clérigos procedentes de Menorca $^{29}$ o religiosos

24 Carta del vicario general de Menorca al obispo de Mallorca, 31 de diciembre de 1767. AGS, Estado, 6968, s. fol.

25 AGS, Estado, 6834, exp. 125, s. fol.

26 Órdenes dictadas por Richard Kane, gobernador de Menorca. AGS, Estado, 6834, exp. 125, s. fol.

27 Carta de fray Alonso de Talavera —obispo de Cádiz- a José Grimaldo, 19 de marzo de 1713. Archivo Histórico Nacional (en adelante AHN), Estado, 760, s. fol.

28 Dos cartas del marqués de Monteleón — embajador en Inglaterra - al marqués de Grimaldo, Londres a 20 y 27 de febrero de 1716. AGS, Estado, 6834, exp. 25, s. fol., y 6835, exp. 4, s. fol.

29 Los gobernadores gibraltareños tenían preferencia por los sacerdotes menorquines por su condición de súbditos británicos. Entre ellos destacaron los hermanos Messa (Francisco y Rafael), quienes ocuparon el puesto de párroco sucesivamente. Rafael se caracterizó por actuar al margen del obispo de Cádiz hasta el punto que no contestaba las cartas que le enviaba el prelado en la línea de su decisión de cortar las relaciones con la diócesis. (Crespo, 2014, p. 269; Benady, 2017, pp. 331-332). 
franciscanos afectos a los gobernadores desarrollaran labores espirituales en Gibraltar —incluidas las de párroco - sin el permiso previo del titular de la diócesis de $\mathrm{Cádiz}^{30}$. De este modo el ejercicio clerical sin licencias del ordinario de la diócesis se situaba al margen de la ortodoxia canónica, hasta el punto que podían ser anuladas las actuaciones eclesiásticas e, incluso, los sacramentos impartidos. No obstante, los perjuicios que podían causar en los católicos gibraltareños la invalidación de los ritos y celebraciones practicadas hicieron que los prelados de Cádiz se vieran condicionados a aceptar — en ocasiones, en secreto - los nombramientos realizados por el gobernador británico atendiendo al «bien espiritual de las almas» ${ }^{31}$.

La imposibilidad de efectuar una selección de los candidatos para ocupar los cargos sacerdotales en Gibraltar hacía que los designados por las autoridades inglesas no dispusieran, en general, de cualidades idóneas para desempeñar sus labores en el seno de la Iglesia católica, aunque ello no era óbice para que contaran con la protección y apoyo del gobernador de la plaza frente a cualquier decisión que adoptaran los titulares de la diócesis gaditana o el provincial de su orden religiosa. En efecto, una parte de ellos habían renegado de la vida conventual y habían llegado a la Roca para disfrutar de costumbres más profanas y relajadas, y acostumbraban a relacionarse con los militares de alto grado de la guarnición, la élite comercial y el gobernador (Bethencourt, 1967, p. 61); no destacaban, pues, ni por sus virtudes teologales ni por mantener la ortodoxia de la Iglesia de Roma. Así sucedía, entre otros, con el padre Rojas, a quien el prelado Tomás del Valle describió como clérigo alejado del cumplimiento de la regla franciscana y mendicante, desligado de la comunicación con sus superiores (no respondía a las cartas del obispo), sospechoso de tratar con los «herejes» anglicanos y sujeto al vicio de una extrema embriaguez, lo que hacía que muchos vecinos de Gibraltar llevaran a bautizar sus hijos a Marbella o Estepona ante la duda de si recibirían el sacramento correctamente ${ }^{32}$. Asimismo, los dos clérigos que posteriormente asumieron el cargo de párroco tampoco brillaron por sus méritos morales y espirituales. En concreto, a uno de ellos fray Francisco Ignacio Jiménez lo definió como «entregado al trato, contemplación y obsequio de los ingleses», mientras que el obispo gaditano consideró al religioso que le sucedió como un «hombre viejo, inepto limitado, muy adulador de la facción del gobierno y muy contemplativo», que tenía a los católicos abandonados, desamparados, desconsolados y ausentes de dirección ${ }^{33}$.

30 AGS, Estado, 6984, exp. 2266 y 2271 correspondientes al año 1772 . Y carta del obispo fray Tomás del Valle remitida al marqués de la Ensenada, Puerto Real a 30 de junio de 1749. AGS, Estado, 6832 , s. fol.

31 Carta de Joaquín de Mendoza y Pacheco — comandante general del campo de Gibraltar- enviada al marqués de Grimaldo desde el Campo de Gibraltar el 7 de octubre de 1771. AGS, Estado, 6981, s. fol. Ibidem. 
De igual modo, Diego Tabares — comandante general del Campo de Gibraltar — tampoco tenía una buena opinión del párroco fray Francisco Hinojosa - franciscano descalzo - , a quien había tratado y calificaba en 1768 de «sujeto corto de talentos, de pocos modales, e ignorante», estimando que no era un sacerdote «a propósito para la expresada iglesia, donde se requiere un eclesiástico de alguna ciencia, conciencia muy ajustada, celo discreto para que pueda ejercer su ministerio con fruto espiritual» ${ }^{34}$. Además, lo conceptuaba como un clérigo insubordinado al juez eclesiástico superior y, en este sentido, lo calificaba de «Anti-Papa». Incluso fue objeto de una denuncia anónima que lo responsabilizaba de haber destinado a otros menesteres los donativos de católicos andaluces y gibraltareños que habían sido efectuados para llevar a cabo las obras de la iglesia parroquial (Bethencourt, 1967, p. 74). A pesar de estas características reseñadas y de los intentos realizados por la jerarquía eclesiástica hispana para removerlo de Gibraltar no lo consiguieron, ya que supo granjearse la protección de los jefes británicos.

Desde luego, en la selección de los párrocos practicada por los responsables políticos ingleses no parecía prevalecer la valoración de la catolicidad de los candidatos si tenemos en cuenta que en el caso del fraile franciscano Miguel Vallés se trataba de un religioso fugado de su convento de Valencia que, según el cónsul español en Gibraltar, se negaba a volver, como también a acatar los mandatos del provincial y general de la orden, hasta el punto de que manifestó públicamente en las calles de Gibraltar que «se volvería de la religión protestante» antes que regresar a su lugar de procedencia $^{35}$.

Con este panorama de clérigos inmersos en la relajación de las costumbres y ajenos a la ortodoxia eclesiástica, la excepción la protagonizó el cura Juan Romero Figueroa, párroco de la iglesia mayor de la Roca y hombre culto, quien se encontraba en el Peñón cuando se produjo la conquista por la armada angloholandesa en 1704. Con posterioridad dedicó sus esfuerzos a cuidar su templo, atender las necesidades espirituales de los católicos, impartir los sacramentos, mantener la comunicación con el obispo de Cádiz como superior eclesiástico, proteger las imágenes y objetos sagrados, y dar cobijo en la parroquia a una escuela católica a la que acudían 30 muchachos, a la vez que se adoctrinaba al resto de los niños mediante catequesis organizadas durante las tardes de los días festivos (López, 1782, pp. 307-312; Bethencourt, 1967, p. 32). Fue un ejemplo de aceptación de la jurisdicción diocesana frente a la mayoría de los párrocos, quienes prefirieron complacer a las autoridades gibraltareñas lejos de las ataduras de dependencia respecto al prelado gaditano.

34 Carta de Diego Tabares enviada a Juan Gregorio Muniain, Campo de Gibraltar, 6 de abril de 1768. AGS, Estado, 6968, s. fol.

35 Carta de Francisco García Caballero enviada al marqués de Grimaldo, Gibraltar a 27 de mayo de 1718. AGS, Estado, 6841, s. fol. 


\section{El posicionamiento de la Santa Sede}

El hecho de que el cumplimiento del tratado de Utrecht fuera una cuestión que implicaba a una potencia no católica como Gran Bretaña, en la que el Romano Pontífice no era cabeza de la iglesia anglicana, limitaba sobremanera su capacidad de actuación en los territorios de dominio inglés. De ello era consciente la propia Monarquía Hispana, pues recurría a la Santa Sede casi en exclusiva para informarle de la situación religiosa de Gibraltar y Menorca y solicitarle que deliberara al respecto con el fin de consolar a los fieles católicos y resolverles las dudas espirituales que surgían ante las órdenes dictadas por las nuevas autoridades de ambas plazas ${ }^{36}$. De todas formas, las medidas adoptadas por los gobernantes británicos generaron en Menorca una gran preocupación y una actitud muy activa en la jerarquía eclesiástica y en los representantes del colectivo católico, quienes trataron de implicar de alguna manera al Santo Padre con objeto de encontrar una solución respetuosa con la práctica religiosa tradicional de los menorquines. En efecto, el obispo de Mallorca imploraba el «paternal amparo» del Papa para que atendiera a los feligreses de la isla por «todos los modos y medios» a su alcance teniendo en cuenta los acontecimientos que le relataba el mencionado prelado en 1712, un año antes de la firma del acuerdo de paz:

Smo. Padre [...] en el cuidado que ocassiona al presente la violencia de los inglesses en la isla de Menorca, sugeta a este obispado, donde hallándose con algunas fuerzas no solo molestan a los naturales contra todo respeto de la Alianza, sino también los amenazan, que han de dominar brebemente con absoluta libertad aquel territorio perturbando todas las reglas de equidad con que al principio entraron: y recelando yo con justa causa que si llega el casso de esta tropelía padezca notable o total ruyna todo lo eclesiástico, y la religión cathólica [...] todo lo qual hace más sensible y digno de la mayor atención el presente peligro con que se halla insultado el catholicismo ${ }^{37}$.

Una inquietud semejante manifestaba el cardenal Zondadari, nuncio en Avignon, en una misiva dirigida el cinco de septiembre de 1714 al cardenal Paulucci

36 Carta del cardenal Acquaviva —embajador español en Roma- redactada el 16 de marzo de 1717. AGS, Estado, leg. 6834, exp. 127. En este sentido, Juan de Elizondo — secretario de estado- le manifestaba lo siguiente al marqués de Grimaldo en un documento emitido en Madrid el 16 de octubre de 1716: «[...] se ha servido el Rey (Dios le guarde) mandar se forme un extracto de todo lo subcedido en este gravíssimo negocio, para remitiese al cardenal Aquaviva con los demás papeles, y noticias de este asumpto a fin de que poniéndolo en manos de su Beatitud se sirva de deliverar lo que deverá executarse en los puntos que comprehenden contra nuestra sagrada Religión [...], esperándose de Roma la resolución de su Santidad». AGS, Estado, 6834, exp. 120, s. fol.

37 Documento redactado en Mallorca por su obispo el 26 de septiembre de 1712. ASV, Segr. Stato, Vescovi e Prelati, 119, f. 148. 
— secretario de estado de la Santa Sede_-, pues consideraba que el edicto publicado en Menorca por Richard Kane - comandante inglés - el 17 de mayo de ese mismo año propiciaba el contagio y extensión del anglicanismo entre los habitantes de la isla ${ }^{38}$. Por su parte, los diputados del estado eclesiástico de Menorca se mostraron muy activos ante la administración pontificia al requerir directamente en 1722 la intervención de Su Santidad. Con tal finalidad se presentaron en Roma ante el cardenal secretario de estado con objeto de que les consiguiera una audiencia con el Papa para tratar «artículos de dogma y de gobierno económico eclesiástico»» ${ }^{39}$.

La curia romana prefirió, sin embargo, situarse en un segundo plano, a pesar de las comunicaciones efectuadas por el obispo de Mallorca, el nuncio y los diputados menorquines. Tanto es así que se circunscribieron a alabar el interés que se había tomado el monarca hispano por esta materia, a celebrar una reunión de la congregación del Santo Oficio para estudiar las irregularidades religiosas acontecidas y a dejar constancia de que el remedio de la situación debía proceder de las negociaciones diplomáticas que desarrollara el embajador español en la corte de Londres ${ }^{40}$. En el contexto de esta línea de prudencia pontificia, el cardenal Acquaviva advertía que desde Roma poco se podía obrar y sugería que se recurriera a las potencias que habían mediado en el tratado de Utrecht con el fin de que influyeran en su cumplimiento. Por tanto, habría que esperar a fines del siglo XVIII para que se produjera una clarificación jurisdiccional diocesana, ya que en 1795, durante un nuevo período de dominio español, fue cuando se procedió a la creación de un obispado independiente en Menorca segregado de Mallorca (Morcillo, 2015, p. 25). Por el contrario, el Peñón permaneció formando parte del obispado de Cádiz durante todo el siglo XVIII, al menos a efectos teóricos, si bien resulta evidente que la supervisión y control de los clérigos gibraltareños por parte del prelado distaba mucho de que fuera una realidad, tal como hemos tenido la oportunidad de comprobar en las páginas precedentes. La solución al conflicto jurisdiccional comenzó a surgir a principios del siglo XIX cuando, por decreto de la Sagrada Congregación de Propaganda Fide, Pío VII nombraba el 28 de junio de 1806 vicario general del obispo de Cádiz en Gibraltar a Isidro Domínguez — sacerdote de la congregación de clérigos menores de la provincia Bética- con todas las facultades ordinarias que correspondían al prelado gaditano, excepto las que necesitaban carácter episcopal hasta que se resolviera la incomunicación y oposición de las autoridades británicas (Antón, 1993, pp. 65-66). Dado que ambas circunstancias impeditivas continuaron produciéndose, se inauguraba así el camino de la segregación respecto a la diócesis de Cádiz y su dependencia directa de la Santa Sede.

38 ASV, Segr. Stato, Spagna, 213, f. 272-274.

39 Carta del cardenal Acquaviva dirigida al marqués de Monteleón —embajador español en Londres-, Roma a uno de septiembre de 1722. AGS, Estado, 6852, s. fol. 
Con estos antecedentes y hechos, la defensa de la jurisdicción eclesiástica católica difícilmente se pudo mantener indemne ante un poder militar y civil efectivo en los territorios que pasaron al dominio británico durante la guerra de Sucesión. Por ello, los clérigos que realizaban labores espirituales en Menorca y Gibraltar estaban obligados a desenvolverse en un espacio sinuoso y fronterizo entre la voluntad de los gobernadores ingleses y las reglas canónicas que establecían la dependencia religiosa de las diócesis hispanas.

\section{En torno a la práctica del catolicismo}

ARTÍCULO X. Promete también su Magestad la Reyna de la Gran Bretaña que a los habitadores de la dicha ciudad de Gibraltar se les concederá el uso libre de la religión católica romana $[\ldots]$

ARTÍCULO XI. Promete también [...] que todos los habitadores de aquella Isla (de Menorca), tanto eclesiásticos como seglares, gozen segura y pacíficamente de todos sus bienes y honores, y se les permita el libre uso de la religión católica romana; y que para la conservación de esta religión en aquella Isla se tomen aquellos medios que no parezcan enteramente opuestos al gobierno civil, y leyes de la Gran Bretaña $^{41}$.

(Tratado de Utrecht, 1713)

Si bien los acuerdos de paz de Utrecht posibilitaban la conservación de los cultos y creencias católicas en Gibraltar y Menorca, la ambigüedad de su redacción por hacerlos depender de todo aquello que no fuera opuesto al «gobierno civil y leyes de Gran Bretaña» originaba ciertos márgenes para la interpretación restrictiva del principio del libre ejercicio de la religión. Por tanto, aunque la administración española y los embajadores enviados a la corte de Londres defendieron frecuentemente ese derecho de carácter general en materia religiosa, la monarquía inglesa se resistió a facilitar que hubiera determinadas prácticas que pudieran limitar la capacidad de actuación política y jurídica de los gobernantes que regentaban ambas plazas.

Es evidente, tal como se ha señalado en páginas anteriores, que la aplicación de la jurisdicción eclesiástica era una cuestión que los británicos consideraban que generaba interferencias con el poder civil del Estado, pero, además, la mencionada ambigüedad del tratado fue interpretada de forma excesivamente amplia, de manera que los gobernantes británicos expulsaron a clérigos ${ }^{42}$, se entrometieron en su selección y nombramientos, secuestraron rentas correspondientes a los canónigos y al

41 Colección de los tratados, 1796, vol. 1, pp. 249-250.

42 AGS, Estado, 6834, exp. 141, s. fol. 
cabildo catedralicio de Mallorca ${ }^{43}$, permitieron la entrada en los templos de manera irrespetuosa ${ }^{44}$, convirtieron algunos lugares sagrados de Gibraltar en almacenes (Domínguez Ortiz, 1996, p. 310), dificultaron la impartición del sacramento de la confirmación por los prelados, favorecieron que los creyentes se relajaran en el cumplimiento de las reglas de la Iglesia romana, protegieron a eclesiásticos que habían adoptado conductas recriminables en la moral católica e impidieron que la jerarquía diocesana penalizara esos comportamientos, aceptaron la llegada y asentamiento de judíos y musulmanes, entre otras cuestiones.

Los hechos mencionados avalaban las reivindicaciones expresadas por Juan Bayarte — diputado general de Menorca - , quien se desplazó a la ciudad de Londres, bajo la protección del embajador español, para solicitar y requerir al monarca inglés que se cumplieran tanto el mencionado convenio de paz como las capitulaciones acordadas con el duque de Argyll cuando tomó posesión de la isla, puesto que pese a lo prometido estimaba que no se estaban respetando los fueros, costumbres y "privilegios eclesiásticos $\rangle^{45}$. Estas pretensiones del citado representante de la comunidad católica estaban en la línea de las negociaciones realizadas por la diplomacia hispana con motivo del tratado de paz y amistad concluido entre las coronas de España e Inglaterra el 13 de junio de 1721, en el que el rey Jorge I dejaba abierta la posibilidad de que «el libre uso de la religión» en Menorca fuera uno de los epígrafes de la paz de Utrecht que en esa fecha no habría sido cumplido por Gran Bretaña en su totalidad (Colección de los tratados, 1801, vol. 3, pp. 96-97). Desde luego, la práctica del catolicismo se constituyó en una constante analizada en las relaciones diplomáticas entre ambos países a lo largo del siglo XVIII y un aspecto tenido en cuenta cada vez que se producía un traspaso del dominio de Menorca. En efecto, sirvan como muestra las capitulaciones tratadas entre Juan Nepomuceno de Quesada — gobernador español de la isla - y el general Charles Stuart. En ellas, se aceptaba por el militar inglés, el 16 de noviembre de 1798, «asegurar a los habitantes pacíficos en el goce de su religión y propiedad», pero como ya había sucedido con el tratado de Utrecht en 1713 se dejaba cierta imprecisión en el compromiso concertado, ya que manifestaba que los artículos solicitados en materia religiosa por el representante hispano no pertenecían propiamente a la capitulación ${ }^{46}$.

43 AGS, Estado, 6834, exp. 148, s. fol.

44 AGS, Estado, 6834, exp. 145, s. fol.

45 Carta de Juan Bayarte a Juan Bautista de Orendain y Azpilcueta — marqués de la Paz y secretario de Estado- Londres a 8 de agosto de 1726. AGS, Estado, 6867, s. fol.

46 El gobernador español pedía al general británico, entre otros, los siguientes artículos: «11.- Al vecindario y población de esta Isla, se le ha de dejar vivir en el libre uso de la religión, gozando pacíficamente las haciendas, bienes y privilegios que tienen y disfrutan al presente. 12.- La silla Episcopal de la Isla quedará establecida en ella, con arreglo de la Bulla de nueba erección gozando su Illma. los honores, authoridad, y rentas propias del obispado, y subsistiendo con su cabildo eclesiástico sufragáneo del Arzobispado de Valencia». Archivo General Militar, Madrid (en adelante AGMM), 7-34, f. 9-10. 
A pesar de los incumplimientos reseñados y de las vicisitudes que tuvieron lugar a lo largo del siglo XVIII, la convivencia entre católicos, anglicanos y otras religiones no generó conflictos destacados de carácter permanente, siendo viable la práctica de los diferentes credos. En este sentido, Ignacio López de Ayala — catedrático y académico de la Real Academia de la Historia - afirmaba en 1782 que en Gibraltar, después de décadas de dominio británico, se daba una cierta coexistencia pacífica entre habitantes de diversas procedencias geográficas y religiosas a causa de la regulación legal y punitiva ejercida por las autoridades del Peñón:

Era de temer por la diversidad de religiones, de costumbres e intereses de los habitantes, que se experimentarán en Gibraltar las pendencias i atrocidades que en otras ciudades de la provincia. La severidad del gobierno militar las ha precavido; porque certificados los individuos que allí concurren, de la pena que les amenaza en caso de incurrir en algún delito [...], i por un efecto de leyes tan bien establecidas como observadas pasan muchos años sin que se vean los asesinatos i violentas muertes que en otras poblaciones más pequeñas i de vecinos uniformes en religión i leyes (López, 1782, p. 373).

De este modo el catolicismo permaneció vigente a lo largo de la centuria en la Roca. Ni las adversidades originadas por las restricciones a la jurisdicción eclesiástica, ni la ocupación de determinados lugares sagrados para funciones políticas, militares o de almacenamiento, ni la relajación de las costumbres de los clérigos fueron obstáculos insalvables para que continuara perviviendo el credo de la iglesia romana. La solidez de las raíces religiosas evidenciada a principios del siglo XVIII entre los gibraltareños posibilitó su persistencia en las décadas siguientes (Domínguez Ortiz, 1996, p. 304).

Por su parte, los menorquines se mantuvieron fieles a la doctrina de la Santa Sede durante todo el periodo de dominación inglesa en un contexto de convivencia con las predicaciones de los pastores anglicanos, de reparto de biblias protestantes, y de cultos y ritos practicados por las familias británicas, hebreas y griegas (Menéndez, 1978, p. 340; Ruidavets, 1982, p. 556). Asimismo trataron de situarse al margen del proyecto de creación de escuelas impulsado por las autoridades inglesas que, según el monarca español, podían inculcar las creencias protestantes bajo el pretexto de enseñar el idioma inglés a los niños y jóvenes ${ }^{47}$. Pese a ello no faltaron algunos episodios excepcionales como los acontecidos con los matrimonios de tres religiosas profesas

47 Así lo expresaba el secretario José Rodrigo en un documento remitido a José Grimaldo el 8 de noviembre de 1724: «[...] teniendo el Rey presentes los incombenientes y perjuicios que se seguirían a la conservación de la religión catholica de poner escuelas los ingleses tocando tan inmediatamente a ella la educación de la juventud; ha resuelto S.M. que por su ministro en Inglaterra se hagan instancias en aquella Corte para que los catholicos de dicha Isla no tengan maestros que no lo sean [...] Palacio a 8 de noviembre de 1724». AGS, Estado, 6864, s. fol. 
convertidas al anglicanismo y casadas con británicos, suceso que escandalizó a la población autóctona de Menorca, hasta el punto que el teniente general Blakeney informaba al duque de Bedford el 8 de abril de 1749 que había comunicado a sus oficiales y soldados que serían castigados a partir de entonces todos aquellos que mantuvieran relaciones con monjas por ser, según él, «alborotadores de la paz». De esta manera pretendía impedir «la discordia entre los vasallos de Su Majestad ingleses y españoles» y, al mismo tiempo, evitar — según sus propias palabras - «las revoluciones que con el motivo de la religión atacan todo el género humano» ${ }^{48}$.

Pese a hechos puntuales como los mencionados previamente, el catolicismo se constituyó en el principal elemento de cohesión y de resistencia frente al poder ocupante de la isla, incluso en un instrumento de movilización frente a las autoridades británicas (Crespo, 2014, p. 268; Salice, 2017, p. 141). No obstante, las discrepancias que surgieron en torno a la interpretación del tratado de Utrecht entre los menorquines de origen hispano y los gobernantes de la isla no fueron óbice para que, todavía a fines de la década de los setenta del siglo XVIII, Bernardo Espinalt atestiguara que los ingleses daban muestras de tolerancia dejando «profesar la religión católica» (Espinalt, 1778, p. 389).

Por otro lado, la reconquista de Menorca en 1782 por el duque de Crillón y su integración de nuevo en la Monarquía Hispánica activó en este territorio la tradicional política de unidad en torno al catolicismo promovido por la corona a lo largo de la época moderna. Por tanto, se iniciaba un nuevo periodo que se apartaba de la tolerancia religiosa que existió en la isla durante la etapa de gobierno anglosajona, aplicándose medidas tales como el rebautizo de los niños ingleses a los que se les había practicado el rito anglicano ${ }^{49} \mathrm{o}$ el arresto de mujeres que mantenían relaciones sexuales o se habían comprometido en matrimonio con hombres que servían en el ejército británico (Álvarez, 2012, pp. 232 y pp. 249-250). Por tanto, la administración española no dispensó a los habitantes de origen inglés y creencias anglicanas el mismo trato que durante décadas estuvo solicitando para los menorquines católicos; es decir, «el libre ejercicio de la religión».

$48 \quad$ AGS, Estado, 6914, exp. 19, s. fol.

49 Testimonio de fray Francisco Egan — carmelita calzado irlandés y capellán del regimiento de Ultonia_- Documento publicado en: Apología por los curas, 1783, pp. 357-358. 


\section{A modo de conclusión}

Tras lo visto es evidente que los artículos X y XI del tratado de Utrecht no fueron cumplidos en su integridad en Gibraltar y Menorca durante el siglo XVIII, pues los gobernantes ingleses a pesar de que se comprometieron a respetar el «uso libre de la religión católica» y la potestad sobre los bienes de los eclesiásticos, llevaron a cabo determinadas profanaciones de lugares sagrados, ocuparon una parte de las iglesias y conventos para su utilización con fines civiles, políticos y militares, y destinaron algunos templos católicos a los cultos anglicanos. Aun así, al mismo tiempo se advierte la existencia de una cierta tolerancia, la cual permitió que continuara practicándose la fe católica y celebrándose los ritos propios de la Iglesia de Roma en los edificios eclesiásticos. En este sentido, la coexistencia de diferentes credos, salvo en hechos puntuales, no originó enfrentamientos ni conflictos significativos una vez consolidada la ocupación anglosajona, y ello como consecuencia del intervencionismo de las autoridades del Peñón y de la isla balear en materia de convivencia entre comunidades de distinta procedencia. Este formato de tolerancia, que tenía las lógicas imperfecciones, contrasta con la política de unidad religiosa en torno al catolicismo que se retomó tras la reconquista de Menorca por la corona española en 1782, adoptándose entonces comportamientos represivos e intransigentes respecto a la población con creencias protestantes. Unas actitudes que eran contrarias al espíritu de las exigencias que los diplomáticos españoles habían estado requiriendo durante el siglo XVIII a la corte de Londres en favor de los creyentes de origen hispano.

El capítulo que generó mayores controversias en las relaciones hispano-británicas fue el ejercicio de la jurisdicción diocesana de los obispos de Cádiz y Mallorca, ya que los gobernantes de Gibraltar y Menorca consideraban que este derecho podía interferir en la condición de súbditos de la corona inglesa de sus habitantes. De ahí que les exigieran ofrecer muestras de vasallaje a la monarquía mediante la realización de un juramento de fidelidad y oraciones públicas dedicadas al rey de Gran Bretaña. Estos requerimientos generaron una discusión teológica, dado que el monarca anglosajón era a su vez el cabeza visible de la iglesia anglicana, pues surgió el interrogante de si estas fórmulas de sumisión conducían a una conducta herética.

En este contexto, ambos prelados tuvieron mermadas sus facultades en estos territorios si tenemos en cuenta que no pudieron realizar visitas pastorales, salvo alguna excepción, ni distribuir el sacramento de la confirmación entre los fieles, así como notables dificultades — en multitud de ocasiones insalvables — para efectuar los nombramientos de los clérigos y controlar sus actividades, debido a los obstáculos promovidos por las autoridades del Peñón y de la isla, los cuales, como ha podido verse, contribuían a la relajación de las costumbres de los eclesiásticos y a que no contaran con cualidades idóneas para desarrollar sus funciones espirituales. 
En torno a estas cuestiones el nuncio Zondadari, el obispo de Mallorca y los diputados de Menorca, ante las limitaciones impuestas a las actuaciones jurisdiccionales y a la gestión de los bienes y diezmos por parte de los clérigos, trataron de involucrar a la Santa Sede en una solución que solventara los impedimentos aplicados a los católicos en el ejercicio de sus derechos. A pesar de ello, el Pontífice y el secretario de estado romano adoptaron un posicionamiento consistente en no asumir riesgos hasta el punto de que manifestaron una actitud conservadora al resguardo de la diplomacia hispana, a la espera de una hipotética defensa de los asuntos eclesiásticos por parte de las potencias que negociaron el tratado de Utrecht, en la línea de lo expresado por el cardenal Acquaviva.

\section{AGRADECIMIENTOS}

Este trabajo ha sido realizado en el marco del proyecto de investigación $\mathrm{I}+\mathrm{D} \ll \mathrm{Re}-$ ligión extranjería e identidad europea en la Monarquía Hispánica durante el siglo XVIII: estudio comparativo y análisis de las pervivencias y contrastes» (PGC2018093799-B-100), cofinanciado por el Ministerio de Ciencia, Innovación y Universidades del Gobierno de España y el Fondo Europeo de Desarrollo Regional (FEDER). La edición de este trabajo ha sido posible gracias a la ayuda del Programa de Grupos de Potencial Crecemento concedida por la Consellería de Cultura, Educación e Universidade da Xunta de Galicia al GI-1921 de la USC (Referencia: GPC, ED 431B 2021/06). 


\section{Bibliografía}

Abulafia, David (1994), A Mediterranean Emporium. The Catalan Kingdom of Majorca, Cambridge, Cambridge University Press. <https://doi.org/10.1017/ CBO9780511470639>

ÁlvareZ y CAÑAS, María Luisa (2012), «Cuando la intimidad se interpreta como traición. Menorca 1781», Revista de Historia Moderna. Anales de la Universidad de Alicante, 30, pp. 229-250. <http://dx.doi.org/10.14198/RHM2012.30.14>.

ANTÓN Solé, Pablo (1993), «La situación precaria de la Iglesia Católica en Gibraltar: 1704-1806», Almoraima: revista de estudios campogibraltareños, 10, pp. 62-66.

Apología por los curas del Sagrario de la Santa Patriarcal Iglesia de esta ciudad de Sevilla, sobre el bautismo administrado sub conditione a los ingleses, prisioneros de guerra, que abjuraron sus errores, y pidieron ser admitidos en el gremio de nuestra santa Religión Católica (1783), Madrid, Imprenta de Manuel de Sancha.

Barro Ordovás, Antonio (2019), «El desembarco español en Menorca, 1781», Revista General de Marina, 277, pp. 877-892.

BÉLy, Lucien (2007), L'Art de la paix en Europe. Naissance de la diplomatie moderne XVI ${ }^{\mathrm{e}}$-XVIII ${ }^{\mathrm{e}}$ siècles, Paris, PUF. <https://doi.org/10.3917/puf.bely.2007.01>

Bello Reguera, Eduardo (2004), «Tolerancia, verdad y libertad de conciencia en el siglo XVIII», Isegoria. Revista de filosofía moral y política, 30, pp. 127-140. $<$ https://doi.org/10.3989/isegoria.2004.i30.478>

Benady, Tito (2017), «Inmigración en Gibraltar procedente de las otras colonias británicas del Mediterráneo: Menorca en el siglo XVIII, y Malta en el siglo XIX», Cuadernos de Gibraltar-Gibraltar Reports, 2, pp. 329-338. <http://dx. doi.org/10.25267/Cuad_Gibraltar.2017.i2.15>.

Bernardo Ares, José Manuel (2016), «La historiografía actual sobre la Guerra de Sucesión y los tratados de Utrecht y Rastadt (1702-1714)», Magallanica: revista de historia moderna, 5, pp. 149-165.

Bethencourt Massieu, Antonio de (1967), El catolicismo en Gibraltar durante el siglo XVIII, Valladolid, Universidad de Valladolid.

Borsson, Didier (2018), «Introduction. Tolerance et intolérance des religions en Europe, $\mathrm{XVI}^{\mathrm{e}}-\mathrm{XVIII}{ }^{\mathrm{e}}$ siècles», Annales de Bretagne et des Pays de l'Ouest, 125-1, en línea: $<\mathrm{http}: / /$ journals.openedition.org/abpo/3760>.

Caimari Calafat, Tomeu (2001), «El conflicto sucesorio en el reino de Mallorca: del reconocimiento de Felipe V al dominio austracista (1700-1715)», en La Gue- 
rra de Sucesión en España y América. Actas de las X Jornadas Nacionales de Historia Militar, Madrid, Cátedra «General Castaños», pp. 249-262.

Colección de los tratados de paz, alianza, comercio, etc. ajustados por la Corona de España con las potencias extrangeras desde el reynado del señor don Felipe Quinto hasta el presente. Publicase por disposición del Exmo. Señor Príncipe de la Paz, consejero y primer secretario de Estado, grande de España de primera clase, etc., etc. (1796-1801), vols. 1 y 3, Madrid, Imprenta Real.

Coronas, Santos M. (1996), El libro de las leyes del siglo XVIII. Colección de impresos legales y otros papeles del Consejo de Castilla (1708-1781), vol. 5, Madrid, Boletín Oficial del Estado y Centro de Estudios Constitucionales.

CRESPO, Martí (2014), «Gibraltar i Menorca, les “illes britàniques” a la Mediterrània», en Albareda i Salvadó, Joaquim y Alcoberro i Pericay, Agustí (dirs.), Els Tractacts d'Utrecht: clarors i foscors de la pau, la resistència dels catalans: 9-12 abril 2014: Actes del congrés, Barcelona, Museu d'Història de Catalunya y Universitat Pompeu Fabra, pp. 267-272.

Domínguez, Juan Pablo (2013), «Reformismo cristiano y tolerancia en España a finales del siglo XVIII», Hispania Sacra, 45, pp. 113-172. <https://doi. org/10.3989/hs.2013.038>.

Domínguez Ortiz, Antonio (1994), «La Inquisición ante la pérdida de Gibraltar», Espacio, Tiempo y Forma, Serie IV, Historia Moderna, 7, pp. 185-194. <https:// doi.org/10.5944/etfiv.7-1.1994.3292>.

Domínguez Ortiz, Antonio (1996), Los extranjeros en la vida española durante el siglo XVII y otros artículos, Sevilla, Diputación de Sevilla.

EsPinALT y GARCíA, Bernardo (1778), Descripción general geográfica, cronológica, e histórica de España por reynos y provincias..., vol. 1, Madrid, Imprenta de Pantaleón Aznar.

GonzÁlez Cruz, David (2006), Une guerre de religion entre princes catholiques. La succession de Charles II dans l'Empire espagnol, Paris, Editions de L'École des Hautes Études en Sciences Sociales.

GonzÁlez Cruz, David (2018), «Identidad europea y extranjeros en los dominios de la corona española: los tratados internacionales del siglo XVIII», en González Cruz, David y Gil Tébar, Pilar (coords.), Nacionalidad e identidad europea en el Mundo Hispánico, Madrid, Sílex, pp. 39-68.

GonzÁlez Cruz, David, «La religión en los tratados internacionales de la Monarquía Hispánica durante el siglo XVIII», Hispania Sacra, [en prensa]. 
Hugon, Alain (2002), Rivalités européennes et hégémonie mondiale - modèles politiques, conflits militaires et négociations diplomatiques $X V I^{\mathrm{e}} X V I I I^{\mathrm{e}}$ siècles, Paris, Armand Colin.

KAMEN, Henry (1987), Nacimiento y desarrollo de la tolerancia en la Europa moderna, Madrid, Alianza Editorial.

López de Ayala, Ignacio (1782), Historia de Gibraltar, Madrid, Imprenta de Antonio de Sancha.

MARín, Rodrigo (1704), Sermón en la rogativa solemne, que por la invasión de la Armada enemiga y felicidad de las Armas Cathólicas hizieron, poniendo por intercesora a la Benigna Madre de Misericordia, María Ssma. Sra. Ntra. el Arzobispo y el Cabildo de la Santa Iglesia Apostólica de Granada, en el día de su dedicación diez y siete de agosto, con assistencia del de la muy noble y muy leal ciudad.

Menéndez Pelayo, Marcelino (1978), Historia de los heterodoxos españoles, vol. II, Madrid, Biblioteca de Autores Cristianos.

Morales Ruiz, Juan José (1987), «La masonería en Menorca», en Ferrer Benimeli, José Antonio (coord.), La masonería en la España del siglo XIX, vol. I, Valladolid, Junta de Castilla y León, pp. 383-400.

Morcillo Rosillo, Matilde (2015), Los judios de Menorca durante la segunda mitad del siglo XVIII a través de los protocolos notariales de Mahón (17511802), Menorca, Institut Menorquí d'Etudis. <https://doi.org/10.5354/07188749.2016.44734>

Morgado García, Arturo (2008), La diócesis de Cádiz: de Trento a la desamortización, Cádiz, Universidad de Cádiz.

Salice, Giampaolo (2017), «Le connessioni globali della colonia "scismatica” di Minorca (1743-1785)», Pedralbes, 37, pp. 133-162. <>

Romero Bartumeus, Luís (2014), «Los cónsules que España tuvo en Gibraltar (17161954)», Almoraima. Revista de Estudios Campogibraltareños, 41, pp. 345356.

Ruidavets i Tuduri, Pedro (1982), Historia de la Isla de Menorca, Mahón, Al Thor [reedición].

Te Brake, Wayne P. (2017), Religious war and religious Peace in Early Modern Europe, New York, Cambridge University Press. <https://doi. org/10.1017/9781316104859>

Thompson, Irving A. A. (2001), «The impact of war and peace on government and society in seventeenth-century Spain», en Asch, Ronald G., Voss, Wulft. E. y 
Wrede, Martin (eds.), Frieden und Krieg in der Frühen Neuzeit. Die europäische Staatenordnung und die aussereuropäische Welt, München, Wilhelm Fink Verlag, pp. 160-179.

ToRres SÁNCHEZ, Rafael (2009), «El abastecimiento de víveres al ejército expedicionario de Crillón en Menorca (1781-1782)», en García Hurtado, Manuel Reyes, González Lopo, Domingo L. y Martínez Rodríguez, Enrique (eds.), El mar en los siglos modernos, vol. II, A Coruña, Xunta de Galicia, pp. 413-425.

Tratados, convenios y declaraciones de paz y de comercio que han hecho con las potencias extranjeras los monarcas españoles de la Casa de Borbón. Desde el año 1700 hasta el día. Puestos en orden e ilustrados muchos de ellos con la historia de sus respectivas negociaciones por don Alejandro del Cantillo, oficial que ha sido en la Primera Secretaría de Estado y del Despacho (1843), Madrid, Imprenta de Alegría y Charlain.

Twiss, Richard (1776), Voyage en Portugal et en Espagne fait en 1772 \& 1773, Berna, Societé Typographyque.

Victory, Antonio (1924), Gobierno de Sir Richard Kane en Menorca (1712-1736), Mahón, Imprenta de Manuel Sintes. 